\title{
6 \\ Indigenous Justice and the Right to a Fair Trial
}

\author{
GISELLE CORRADI
}

\section{INTRODUCTION}

$\mathrm{W}$

HEN A STATE endorses legal pluralism and gives official status to more than one legal order, it is often confronted with the task of guaranteeing that all these legal orders comply with human rights. This is frequently the case in postcolonial settings, where next to the legal institutions inherited from former colonial powers, indigenous or customary legal orders are also part of the state architecture for justice provision. As with all legal orders, indigenous law may advance human rights in certain areas, but undermine them in others. At the same time, these legal orders are embedded in historical, cultural and socioeconomic contexts that differ in several respects from those that gave rise to human rights law. For these reasons, evaluating whether indigenous law complies with human rights standards and taking measures for the protection of human rights in legally plural jurisdictions are not straightforward tasks. One issue that has been identified as crucial in this respect is the way in which human rights are interpreted and whether such interpretation adopts a cross-cultural approach (An Na'Im 1992; Eberhard 2002; Sousa Santos 2002). This is one of the legacies of the well-known 'universality debate', which, amongst others, showed that human rights need to be understood in flexible ways in order to respond to diverse realities and be seen as legitimate across different contexts (Brems 2001; Donelly 2007, 1984). In addition, comparative legal scholars have demonstrated that indigenous and customary legal orders do not operate in the same way as the civil and common law traditions that lie at the basis of many state legal orders (Glenn 2000). In other words, one needs to take legal diversity into account. Therefore, assessing the relationship between indigenous legal orders and human rights requires understanding the context in which these legal orders operate as well as their logic, ie their underlying rationales, values, principles and ways of reasoning, which inform particular norms and practices (An-Na'Im 1992; Sanchez Botero 2004). 
This chapter examines how this applies to the right to a fair trial. Previous cross-cultural studies on the right to a fair trial remark this right has been generally understood in a monocultural way, by implicit reference to legal orders of Western origin (D’Engelbronner-Kolff 2001; Padilla Rubiano 2012; Sanchez Botero 2004). The case law of the Constitutional Court of Colombia can be said to constitute an exception. In determining whether the right to professional legal counsel applies to indigenous justice, the Court highlighted that this form of representation is alien to indigenous practices, and that in a plural society, respect for cultural diversity entails no such imposition. ${ }^{1}$ The Court maintained that:

[Indigenous] judgments should be carried out in conformity with the norms and procedures of indigenous communities, taking into account the specificities of each sociopolitical form of organisation, as well as the characteristics of its legal order. $^{2}$

According to the Court, '[W] hat is required is the fulfilment of those steps that the accused can foresee, and respect for those traditional practices that serve as the basis for social cohesion.' ${ }^{3}$ However, the Court provides no guidance on how to evaluate the extent to which indigenous norms and procedures are compatible with fair-trial guarantees. In that regard, some authors argue that a few elements of this right ought to be respected by all legal orders, such as the possibility to defend oneself, the presumption of innocence, the impartiality of the judge, the legitimacy of the procedures and the possibility to appeal (Padilla Rubiano 2012: 92).

Based on a case study conducted in the Aymara indigenous municipality Curahuara de Carangas, in the Bolivian highlands, this chapter identifies a number of elements of the right to a fair trial that raise questions of interpretation when applied to disputing institutions such as those operating in this locality. ${ }^{4}$ The chapter is divided into three sections. Following this introduction, the second section presents the backdrop of the case study. It

1 Constitutional Court of Colombia, sentence T523 of 1997

2 ibid, introductory paragraph (my translation from Spanish).

3 ibid.

4 This case study is based on fieldwork carried out in Bolivia in October 2012 and JanuaryMarch 2013. In Curahuara de Carangas, 41 semi-structured interviews were conducted with indigenous leaders, state justice providers, religious leaders, social workers and litigants. These interviews focused on the procedures followed within indigenous justice forums, the relationship between these and other justice providers available in this town, and how such forms of articulation worked in practice in a number of cases. Four focus group discussions were organised (one with female litigants, two with youngsters aged between 15 and 16, and one with current indigenous authorities) about local perceptions of the different dispute-processing mechanisms available in Curahuara de Carangas. This was complemented by observations at two monthly meetings between indigenous and municipal authorities, and a desk-based literature review on Andean culture, indigenous justice and legal pluralism in Bolivia. In addition, 27 semi-structured interviews were conducted in $\mathrm{La} \mathrm{Paz}$ and Sucre with representatives from the government, civil society organisations, international organisations and local experts. These interviews dealt with the national legal framework regulating legal pluralism and indigenous 
discusses the main characteristics of the justice landscapes in which disputes are handled in Bolivia, including the accessibility of state and indigenous disputing forums and the relationship between these legal orders in law and practice. The third section zooms in on the case study. First, it describes the main features of the indigenous disputing institutions operating in Curahuara de Carangas. And second, it scrutinises the relationship between fair-trial standards and the procedures followed by these disputing forums. Finally, the conclusion reflects on how areas of tension between the former and the latter may be addressed.

\section{THE JUSTICE LANDSCAPES OF BOLIVIA}

Bolivia constitutes an interesting context in which to examine the relationship between human rights, indigenous law and legal pluralism for several reasons. First, indigenous legal orders play a significant role in regulating social relations within indigenous groups, which constitute the majority of the population (Ministerio de Justicia y Derechos Humanos de Bolivia 1999; Red Participacion y Justicia 2010; Santos Sousa and Exeni Rodriguez 2012). ${ }^{5}$ Since the first colonial encounters about five hundred years ago and until recently, these groups and their institutions have been treated as inferior by colonial and postcolonial legal and political regimes, although the models that sustained this repression have changed over time. ${ }^{6}$ Despite these policies, indigenous legal orders continued to operate at grass-roots

justice in Bolivia, as well as the controversies that surround it and how these issues relate to human rights. Insights on these topics were also gathered by participating in a three-day panel at the Congress of the Latin American Network of Legal Anthropologists in Sucre from 24 to 26 October 2012, which counted an overwhelming presence of indigenous leaders who presented and debated their views on the subject.

5 According to the national census of $2001,62 \%$ of the population self-identified as indigenous, whereas the census of 2012 shows a lower percentage of $41 \%$. According to both censuses, the biggest ethnic groups are the Aymara and the Quechua, which together represent about $90 \%$ of the indigenous populations of Bolivia, living mainly in the highlands and the valleys. The remaining 34 indigenous groups inhabit the Bolivian lowlands.

6 Under Spanish colonial rule, a segregationist model was instituted in which 'peninsulars' and 'Indians' were governed by differentiated legal regimes. This allowed indigenous authorities to administer justice amongst indigenous populations according to their practices and customs, but only in minor cases, while serious cases had to be handled by the Spanish authorities. Upon independence at the beginning of the nineteenth century, criollo elites, following 'civilising' discourses and the theory of legal monism, embraced an assimilationist model in which the entire population was subjected to a single body of law, the administration of which was the exclusive faculty of the judiciaries of the newly constituted states. By the mid twentieth century, concerns over the widespread poverty and marginalisation of indigenous populations led to the introduction of an integrationist model, in which indigenous institutions would be protected as long as these populations were not fully integrated into the life of the nation. This model, which framed the 'Indian problem' in terms of class, saw indigenous culture as temporary and bound to disappear as socioeconomic measures would integrate these sectors of the population into modern life (Yrigoyen 2002). 
level, often in a clandestine way, perpetuating a situation of unofficial legal pluralism. This can be partly explained by the legitimacy of these institutions, and partly by the minimal presence of the judiciary throughout the national territory (Albo 2012; Yrigoyen 2002).

The forms of justice practised by these groups today vary, as has the way in which these practices evolved throughout history in response to contact with colonial and postcolonial state law (Albo 2012; Cottyn 2014). In most regions, they constitute the most accessible form of justice for indigenous populations, particularly in rural areas (IACHR 2007; IIDH 2006; Red Participacion y Justicia 2010). 'Ordinary justice', as state justice is called in Bolivia, presents serious problems in terms of physical access, capacity and credibility due to the small budget allocated to the judicial branch (ibid). According to existing studies, state justice covers only $42 \%$ of the territory and is unevenly distributed, extending mainly to urban areas, ie the capital cities of each department (Red Participacion y Justicia 2010). ${ }^{7}$ In addition, it cannot muster sufficient personnel to meet the needs of the population, which translates into serious case backlogs. Moreover, state justice has the reputation of being corrupt and discriminatory towards indigenous peoples (ibid). By contrast, indigenous legal orders operate at the most local levels of social organisation and involve extensive community participation (Fernandez Osco 2000; Ministerio de Justicia y Derechos Humanos de Bolivia 1999; Santos Sousa and Exeni Rodriguez 2012). At the same time, these legal orders present their own challenges. For example, their efficacy diminishes in the case of disputes that reach beyond the level of the community (Albo 2012). From a human rights perspective, these challenges also include reports that in some cases corporal punishments may be administered, the fact that women are often discriminated against, and the existence of procedures that contravene fair trial guarantees (Coordinadora de la Mujer 2009; Ministerio de Justicia y Derechos Humanos 1999).

A second reason why Bolivia constitutes an interesting setting for the purposes of this study is that in recent years the country underwent a remarkable shift in its policies towards indigenous legal orders. The history of denial, exploitation, discrimination and exclusion that until recently characterised state-indigenous relationships generated profound distrust of the state among indigenous peoples, as well as demands for inclusion (Goodale 2009). During the last decade of the twentieth century a number of factors converged, such as a return to democracy, the crisis in the legitimacy of state institutions, the organised mobilisation of indigenous peoples, and the development of international law and jurisprudence framing indigenous demands in terms of human rights. This led to the adoption of constitutional reforms throughout the region that recognised the multicultural composition

\footnotetext{
7 The territory of Bolivia is divided into nine departments, which are further subdivided into provinces and municipalities.
} 
of society, and, to varying degrees, indigenous law and legal pluralism (Sieder 2002; Van Cott 2002; Yrigoyen 2002). In the case of Bolivia, these transformations first crystallised in the Constitution of 1994, which recognised the right to apply customary law in indigenous communities as an alternative form of justice, subject to the Constitution and the laws of the state (Article 171). But it was only with the adoption of the Constitution of 2009 that indigenous justice and legal pluralism were granted a more solid status. Bolivia's current constitutional recognition of indigenous legal orders is actually among the few in the world to reflect the standards that international human rights law establishes with regard to this matter. ${ }^{8}$ The Bolivian Constitution grants indigenous communities the right to administer indigenous law according to their 'cosmovision' (Political Constitution of the Bolivian State 2009, Article 30(14)), while it stipulates that state and indigenous law have the same hierarchy, and that both legal orders are expected to comply with human rights (Political Constitution of the Bolivian State 2009, Article 179).

This new framework for the relationship between state and indigenous law generates unprecedented opportunities for indigenous communities to engage in processes of empowerment and reinvention. At the same time, it offers state and indigenous justice providers the possibility to see each other as peers, which could allow collaborative relationships to flourish. But this is far from automatic. According to Red Participacion y Justicia: 'At present, the coordination and cooperation between ordinary and indigenous justice is generally inexistent' (Red Participacion y Justicia 2010: 68). Moreover, Law 073 on Jurisdictional Delimitation, which was adopted in 2010 in order to regulate the coexistence of state and indigenous legal orders, poses far-reaching limits on the competence of indigenous disputing forums. ${ }^{9}$ Some of the issues that are excluded from their material jurisdiction, such as agrarian and forest law, rape, homicide and assassination, and violations of the integrity of children and adolescents, have often been dealt with by indigenous communities, which opens the door for their criminalisation. ${ }^{10}$ As this chapter argues, instead of imposing these top-down limits, which in practice are rarely enforced, it is the construction of horizontal relationships of trust between state and indigenous justice providers that is needed for the protection of human rights. Collaboration between these

8 Arts 27, 34 and 40 UN Declaration on the Rights of Indigenous Peoples (UNDRIP), and Arts 8(2) and 9(1) the ILO Convention 169. Bolivia ratified ILO Convention 169 in 1991 by Law 1257 and incorporated the UNDRIP into national law on 7 November 2007.

9 The following issues fall outside the scope of indigenous justice: homicide or assassination, rape, violations of the integrity of children and adolescents, crimes against humanity, the trafficking of human beings, arms or drugs, terrorism, corruption, trade and tariff law, crimes affecting the security of the state, issues related to forest and agrarian law, labour, social security, tax, information, mining, hydrocarbons, and civil law issues in which the state is a party to the conflict (Law 073 Art 10 [II]).

10 See Barrera (2011) for a detailed discussion of Law 073. 
actors, particularly at local levels, is key in the emergence of cross-cultural ways of interpreting human rights and enhancing their implementation at the grass roots.

\section{THE CASE STUDY: CURAHUARA DE CARANGAS}

Curahuara de Carangas is an indigenous rural municipality at the northwest of the Oruro department, in the Bolivian highlands. ${ }^{11}$ Its territory coincides with the Aymara territorial and sociopolitical unit of organisation, the Kurawara Marka, which groups fourteen ayllus. ${ }^{12}$ There are a number of roads one may take to arrive in Curahuara, but when coming from Oruro, the nearest important city, it takes a trip of 4-6 hours (depending on the means of transport) on a zigzagging route across the seemingly desolated Andean high plateau, at about 4000 meters above sea level. But despite its remoteness, Curahuara is not isolated. Of its 6,000 inhabitants, only a minority reside in town permanently. ${ }^{13}$ Most Curahuareños spend their life between the town and their fields, where they herd camelids and sheep, in combination with cultivating subsistence crops. The low profits generated by these activities encourage most Curahuareños to migrate temporarily to nearby regions, where they engage in seasonal work or commercial activities. ${ }^{14}$ Lately, permanent migration to urban centres has been on the increase as a result of increasing poverty, although in many cases Curahuareños keep their communal ties and rights to land by returning temporarily to take on the role of a cargo and/or take part in the annual festivities (Municipal Government/Council of Indigenous Authorities 2007). ${ }^{15}$

11 Whites and mestizos are rare in Curahuara de Carangas because the region was never found economically attractive by these groups since there are no haciendas nor mining activities in this area.

12 Aymara is the dominating ethnolinguistic group of the Bolivian Highlands. Its sociopolitical and territorial organisation rests on various layers of authority and group formation, which are linked to the control of land. The ayllu groups a number of families and constitutes the basic unit of institutionalised community ties linked to a communal territory. This territory may be discontinuous and divided into different zones that are complementary in terms of ecological resources, including communal land that is allocated to a family (sayaña), and areas that are for the common use of a group of families (saraqa). A number of ayllus form a marka, which is the space of encounter at the village level. A marka is divided into two complementary moieties aransaya and urinsaya. In the case of the Kurawara Marka, there are seven ayllus in each of these moieties, totalling 14. A number of markas in turn form a suyu. The Kurawara Marka belongs to the suyu Jach'a Carangas, which groups 12 markas.

13 About $10 \%$ of the population according to the Plan de Desarrollo Municipal Originario 2007-2011 (Municipal Government/Council of Indigenous Authorities 2007).

14 Around $95 \%$ of the population of Curahuara live in poverty (Municipal Government and Council of Indigenous Authorities of Curahuara 2007).

15 The term cargo refers to positions of leadership at the level of the ayllu and the marka. A number of interviewees reported that those community members who live in the city and return to the community for the period of one year to perform a cargo often have difficulties in administering indigenous justice, as they are less acquainted with the norms and practices of the community. 
This inner and outer mobility enable the reproduction of Aymara institutions, while at the same time allowing for contact with state structures and the wider society. ${ }^{16}$ The latter is also facilitated by the presence of a number of institutions representing the state at the local level. The town has three schools, a health post, the office of the mayor, a civil registry, a court of first instance, an environmental court, a police post, a military post and a local representation of the Ombudsman. In addition, there are two evangelical churches and a Catholic one. Moreover, Curahuara de Carangas has been awarded the title of 'exemplary municipality' due to the high levels of articulation between state and indigenous authorities (Municipal Government 2009). ${ }^{17}$ As such, it constitutes an interesting site to study the relationship between different normative regimes.

The remainder of this chapter focuses on these relationships from two angles. First, it describes the procedures of indigenous disputing institutions in this locality and analyses how they relate to fair-trial standards, while reflecting on aspects of this right that raise questions of interpretation in relation to these institutions. And second, it explores how different forms of interaction between state and indigenous justice providers may open and close spaces in which tension between human rights and indigenous law may be addressed in a cross-cultural manner.

\subsection{Indigenous Disputing Institutions in Curahuara de Carangas}

The most common types of dispute handled by indigenous justice in Curahuara de Carangas are conflicts over the delimitation of land plots, the trespassing of animals from one plot to another causing crop damage, theft, intra-familial and marital conflicts, and fights among community members, which may include physical and domestic violence. ${ }^{18}$ Although there is some variation in the practices followed by the different ayllus of the Kurawara

\footnotetext{
16 According to Rodas Arano (2013: 60), such internal and external forms of mobility have been part and parcel of 'Curahuaran culture' for centuries. This is rooted in herding practices, which require and lead to mobility. However, such practices are currently under transformation with the introduction of development projects that aim at increasing the productivity of herding activities by introducing fences. This author argues that fences reduce mobility and change the perception of camelids and the territory (ibid). At another level, the capacity of the Curahuareños to reproduce elements of Aymara culture while participating in the broader society is quite visible in language: Aymara is the first language, followed by Spanish, with $80 \%$ of the population being bilingual (Municipal Government and Council of Indigenous Authorities of Curahuara 2007). Some indigenous leaders also reported that they had held positions of authority in state structures, eg as mayor, or responsible for the civil registry.

17 Indigenous and municipal authorities meet twice a month on Sunday to explain and discuss issues affecting Curahuara de Carangas in an open forum where everybody can participate. Moreover, the office of the mayor and that of indigenous authorities are housed in the same building.

18 Rape was also mentioned as an offence that may be solved by indigenous authorities, although many interviewees explained that these cases are often transferred to the police.
} 
Marka, the following elements can be said to constitute a common core of the dispute process. ${ }^{19}$

In general, the aggrieved party presents her complaint to the authorities of the ayllu, although in the case of marital conflicts, the relatives and padrinos of the couple tend to be approached first. ${ }^{20}$ An ayllu may be divided into several zones and the aggrieved party normally brings the case first to the authority of her zone, the sullka. However, in some cases, she may approach directly the main authority of the ayllu, the awatiri. ${ }^{21}$ There are no strict rules concerning this and the procedures followed at both levels are basically the same, but even if the parties first tried to solve the case with the sullka without success, the case can still be transferred to the awatiri. ${ }^{22}$

These positions of communal leadership are characterised by a number of principles, such as chacha warmi, service to the community, thaki, rotation and consensus, which influence the way in which indigenous authorities exercise jurisdictional functions (Flores Condori 2012: 39). Chacha warmi refers to the man-woman complementarity that exists in a couple, and in general, it is married couples that are elected to perform a position of leadership together. ${ }^{23}$ Appointment to such positions is considered a duty and a service to the community, which is related to the concept of thaki or 'movement along a path' (Canessa 2012). Every adult member of the ayllu is expected to follow this path, in which life experience, knowledge and maturity are accumulated, eg as sullka, later as awatiri and eventually as

19 It was beyond the scope of the fieldwork to gather detailed primary data on the extent to which 'an Andean cosmology' informs different elements of these disputing practices. There is ample evidence in anthropological sources that several aspects of indigenous life in this region are underpinned by relationships of reciprocity with different forces of the cosmos. For example, Canessa explains that the relationship between jaqis (indigenous people in Aymara) and the surrounding environment should be understood in terms of intimacy with an animated landscape (Cansessa 2012: 162). At the level of law and justice, Fernandez Osco argues that according to Aymara normativity, human actions have repercussions beyond the human world. For example, abortion is sanctioned because it affects the agricultural cycle (Fernandez Osco 2000, 2009). Although I did not come across such statements in Curahuara de Carangas, interviewees did emphasise the importance of symbolic rituals that accompany dispute-processing practices, reflecting the interconnection among community members and the pachamama (earth goddess).

20 The padrinos are the godparents of a couple, who are expected to give guidance and council, particularly at difficult times.

21 The term awatiri can be translated as 'shepherd', and in fact, the awatiri is expected to perform the function of guiding the members of the ayllu as a shepherd would guide his sheep, or as an 'eldest brother' who takes care of the wellbeing of the community. The terms tamani and jillakata are also used to refer to this position. The terms sullka awatiri and sullka tamani could be translated as 'young brother'. In practice, the sullka acts as an assistant of the awatiri in a certain zone of the ayllu, but has no political authority.

22 In general, if the sullka has a stake in the conflict, or if the parties simply do not consider him fit to deal with it, a case will be brought directly to the awatiri.

23 Although in some circumstances, a non-married person may be chosen too. In addition, the role of men and women is not equal. The latter rarely take a leading role in public decision making (Flores Condori 2012; Gadea 2010) 
mallku. ${ }^{24}$ As a result, authority is rotational, implying high levels of downwards accountability. On their first day as authorities on 1 January, the awatiris and the sullkas are expected to visit each family and get acquainted with the 'state' of their ayllu, which they will lead for one year. In the case of the awatiris, their responsibilities entail both judicial and political functions, such as chairing ayllu assemblies, coordinating (and often sponsoring) the organisation of yearly rituals and festivities, the governance of land and other community resources, as well as the settlement of disputes. The decision-making processes involved in these activities are characterised by dialogue and seeking consensus. Authorities are elected democratically by the members of the ayllu, and are expected to capture and give expression to the common will. ${ }^{25}$

After receiving a complaint, the awatiri or the sullka fix a date on which both parties can attend a 'hearing'. ${ }^{26}$ The aim of such hearings is to arrive at a decision that both sides find acceptable, even if only temporarily, so that they can continue to live side by side, avoiding the disruption of community activities. It is the responsibility of the awatiri or the sullka to understand the origins of the conflict, in order to be able to facilitate a consensual agreement. Moreover, if one or both parties are found to be 'at fault', the sullka or the awatiri need to make the person(s) understand what was wrong and why, regret it and apologise. In other words, indigenous authorities are expected to correct bad behaviour. This may extend beyond the individual who committed the fault. For example, the blame may also fall upon relatives who failed to guide a person into following the right conduct. The body of norms that influence such appraisals is oral and of general knowledge amongst community members, although these norms may be contested at some point. ${ }^{27}$

A typical hearing starts with a series of rituals that symbolise the interconnectedness among community members and the pachamama (earth goddess), such as sharing coca leaves and a drink (often alcohol), and rituals of libation called ch'allas. After reminding the parties that they should speak the truth since they are in front of holy symbols, the authorities listen to both sides. $^{28}$ The parties are normally accompanied by witnesses, who present

24 The mallkus are the indigenous authorities at the level of the marka.

25 Although there is a certain flexibility, typical requirements to become an authority are to be married, to work the land and make contributions to the ayllu, to have had fulfilled other positions of authority, to have reached a certain age (which varies depending on the function), and to reside in the community for the duration of the function.

26 The Spanish word used by the interviewees was audiencia, which is the same word used by state justice to refer to a hearing. If one of the parties is not present, the hearing is postponed.

27 For example, the relatively recent introduction of fences in the context of herding activities has led to disputes in which indigenous practices regarding communal uses of land are questioned (Rodas Arano 2013).

28 The awatiris officiate their hearings in front of the the 'Re-Patron and the Re-Maria', whereas the mallkus do it in front of the Santa Wara, a stick symbolizing ruling power. 
their testimonies too. On this basis, the authority makes an analysis of the case and proposes how it should be settled. This leads to further discussions, after which an agreement may be finally negotiated. A sanction or compensation may be in order when the damage caused is considered significant, or in cases of recidivism. But the authority may simply call the attention of the person in fault, should he consider that this may suffice to correct the deviant behaviour. In most cases, sanctions and forms of compensation entail manual work (for the community or the aggrieved party) such as making a certain number of adobe bricks, the restitution of stolen goods and/or the payment of a fine. ${ }^{29}$ This is negotiated case by case, based on the discretion of the authority about what is appropriate, and what is acceptable to the parties involved. Agreements are sealed by sharing a drink, which symbolises the re-establishment of normal relationships. In some cases, the agreement is written down in a document called an acta, although not all authorities follow this practice consistently. ${ }^{30}$ In principle, compliance with these decisions relies on the voluntary will of the parties. But otherwise, social pressure may serve as a form of coercion, particularly when corporate interests are at stake.

If the authorities consider that the evidence presented at a hearing is not sufficient to understand the facts of a case, they undertake an investigation, for example, by visiting the disputed terrain or the place in which a robbery took place, following footsteps, interrogating other witnesses or looking for documents. When no material forms of proof are available, a juramento may be taken, ie swearing about one's innocence in front of a holy symbol. If the person who swears is lying, it is believed that she/he or his/her family will undergo a calamity, and even death. ${ }^{31}$ As a result, depending on the circumstances, handling a case may involve several steps and hearings. Moreover, some cases may be transferred to a state instance, either as a form of appeal by an unsatisfied party, or as a form of referral when indigenous authorities consider that it is beyond the capacity of indigenous institutions to deal with a certain case. Nevertheless, the timeframe in which disputes are handled by indigenous justice tends to be relatively short, as it is considered important to avoid the escalation of conflicts.

29 According to Gadea, imprisonment in the local cell for a couple of days is a common form of punishment in cases involving physical violence, including domestic violence (Gadea 2010: 72).

30 Several interviewees reported that actas serve as a means of proof of what was agreed in case the conflict should resurface in the future. Contrary to the practice of state courts, these documents were not reported to function as a precedent of how certain types of case should be dealt with.

31 None of the interviewees reported the use of supernatural forms of proof at these hearings, such as the reading of coca leaves. Legal anthropologists working in other Aymara regions found this practice to be quite frequent (Fernandez 2000). A few interviewees mentioned this practice in the context of health-related issues for which a traditional doctor is consulted in order to determine the origin of a disease, although it cannot be excluded that this may be associated to witchcraft accusations leading to disputes. 
Certain conflicts may require the involvement of other levels of indigenous authority. For example, cases that involve several families or that are considered to affect the entire community are brought for discussion at the general assembly of the ayllu. This consists of a monthly meeting, in which community members discuss the issues affecting the ayllu, although in urgent situations an ad hoc assembly may be summoned too. ${ }^{32}$ In these meetings, the testimonies of the parties and witnesses, as well as any element of proof that is available, are considered by the assembly, after which an open debate is facilitated by the awatiri. Taken on the basis of consensus, the decisions of the assembly are mandatory. If an assembly comes to the conclusion that there is no way to correct someone's bad behaviour, and hence, that the restoration of normal relationships is impossible, a person may be sanctioned by banishment from the community. This goes hand in hand with the loss of communal land rights. The decisions of the assembly are enforced by means of social pressure, which may turn into physical violence in case of non-compliance. The accused may contest such decisions, either by involving higher levels of indigenous authority, or by recourse to state authorities. Nevertheless, in general, he/she and often also other members of the family have no choice but to leave the ayllu for reasons of personal safety. Meanwhile, they may stay at their residence in the village, and so remain within the marka, the socioterritorial unit comprising the fourteen ayllus of Kurawara.

Conflicts that involve more than one ayllu are handled by the mallkus, the indigenous authorities at the level of the marka. The procedures followed by the mallkus are basically the same as those followed by the ayllu authorities. The marka has two mallkus, the mallku de marka and the mallku de consejo, representing the two moieties of the marka, aransaya and urinsaya, for which they alternate yearly. ${ }^{33}$ The mallkus receive cases from the ayllus that correspond to their partiality, but occasionally, the two mallkus need to handle a case together, for example when it involves ayllus from the two partialities. From time to time, indigenous authorities are confronted with more 'difficult' cases that require the involvement of both mallkus and the awatiris, such as illegal trafficking or the appearance of a kharisiri. ${ }^{34}$ In very exceptional circumstances, the mallkus may call a cabildo,

32 It is not so much the substance of a case that determines whether it needs to be treated by the general assembly, but a balance between the stakes of the community and the interests and bargaining power of the parties involved. For example, an offence such as adultery may or not be treated by the general assembly depending on these factors.

33 The former deals with the internal affairs of the marka, whereas the latter is responsible for the external relationships.

34 Kharisiri, kharikhari, lik'ichiri and khariri are the terms used in the Andean world to refer to a person that steals the fat of another one, causing his illness and death. A kharisiri can be a man or a woman. He or she will provoke an irresistible tiredness in his victim, normally a lonely traveller. When asleep, the kharisiri will use a device (which can be a syringe or a 'small machine') to extract the fat that surrounds the right kidney of his victim, which is supposed to 
ie an ad hoc meeting of the members of the marka to treat difficult cases in an open assembly.

The next section explores the relationship between these forums' procedures and fair-trial standards. The analysis is concerned with the normativity surrounding these procedures, rather than with these forums' actual practices. Practices may of course deviate from existing norms. As explained in the introduction to this chapter, the point made by the Constitutional Court of Colombia in its judgement 523/1997 is precisely that the practices of indigenous disputing institutions should be appraised against indigenous rather than state procedural law. The discussion is based on recurrent normative discourses collected in the course of the fieldwork about which procedures should be followed by indigenous disputing forums and why. But the normativity surrounding these procedures is not necessarily explicit, let alone written. The characterisation 'indigenous procedural norms' refers to the fact that these norms are applicable in indigenous disputing forums, without entailing that there is anything intrinsically indigenous about them. Some of these procedures may have been inspired by aspects of state procedural law. Similarly, the label 'indigenous' neither implies that the discourses collected are totally homogenous, nor that everybody in this region agrees with them. The aim of the analysis is twofold: to assess the relationship between the procedural norms at play in the indigenous disputing forums of Curahuara de Carangas and international standards, and to reflect on how the latter may need to be interpreted in the context of this examination.

\subsection{Exploring the Relationship between International Fair Trial Standards and Indigenous Procedural Norms}

The right to a fair trial is a composite right with several dimensions, including issues of access to justice as well as requirements imposed upon decisionmaking bodies and their procedures. ${ }^{35}$ These requirements guarantee that decision-making processes resulting in a binding verdict on someone's guilt

be of high value for magical purposes. When the victim wakes up, he cannot remember anything but feels very weak. As time passes, he gets worse, with vomits, fever, etc, until he dies. In the past, the figure of the kharisiri was associated with outsiders, such as priests and foreigners, but nowadays, it can be anyone, particularly persons that do not conform to communal norms and duties (Fernandez Juares 2008; Riviere 1991).

35 In international law, the right to a fair trial is established by Arts 14 and 15 International Covenant on Civil and Political Rights (ICCPR, 1966); Arts 6 and 7 European Convention for the Protection of Human Rights and Fundamental Freedoms (ECHR, 1950); Arts 2 and 4 Protocol 7 to the European Convention for the Protection of Human Rights and Fundamental Freedoms (Protocol 7 ECHR); Arts 8 and 9 American Convention on Human Rights (ACHR, 1969); Arts 7 and 26 African Charter on Human and Peoples' Rights (Banjul Charter, 1981); and Art 40 Convention on the Rights of the Child (1989). It is also included in Arts 10 and 11 Universal Declaration of Human Rights (UDHR, 1948) and Arts 47-50 Charter of Fundamental Rights of the European Union (2000). 
and punishment or on someone's duties and entitlements are made without arbitrariness or abuses of power. In order to achieve these goals, two issues are paramount: the equality of the parties and the objectivity of the decision-maker (Shah 2010; Tapia Pinto 2008). Both elements are interlinked: the fairness of the process entails that the decision-maker is a third party, who can objectively assess and balance the arguments and stakes of two parties that stand equally before him. For this purpose, certain requisites are imposed upon the decision-maker, ie he needs to be independent, impartial and competent. Independency refers to the judge or tribunal being free from external pressures, intimidation and conflicts of interest affecting its decision-making capacities. This entails clear procedures and criteria for the appointment and removal of judges, as well as respect for the principle of separation of executive, legislative and judicial powers. Impartiality means that the judge has no personal bias or interests that may interfere with his appraisal of the case at hand (subjective impartiality). The judge or tribunal must not only be impartial, but also appear so to a reasonable observer (objective impartiality). Finally, his capacity to hear a case needs to be established in advance by law (competent judge). The requirement of equality between the disputing parties means that all individuals ought to have an equal chance to pursue their rights in court (equal access), that all parties are provided with the same opportunities to challenge all the arguments put forward by the other side (equality of arms), and that there is no differential treatment of persons during court proceedings (non-discrimination). In addition, a fair hearing presupposes real and effective access to a court, that hearings are held within a reasonable time, that applicants have a real opportunity to present their case or challenge the case against them, that judgments are (made) public, except in circumstances that justify otherwise, and that courts or tribunals provide reasons for their judgments.

Furthermore, the right to a fair trial encompasses a series of guarantees of due process applicable to criminal proceedings. These include the rights to be informed promptly and in detail of the charge, to defend oneself, and to have adequate time and facilities for the preparation of the defence, to communicate with legal counsel of one's own choice, to examine witnesses and present evidence, and to be tried in person, without undue delay, and all of this in a language understood by the defendant. The accused also has the right not to be compelled to testify against himself or plead guilty, whereas any evidence obtained by coercive means is unacceptable. He also has the right to be presumed innocent, and be declared innocent in case of insufficient proof of guilt (in dubio pro reo). He cannot be charged twice for the same offence (ne bis in idem), or held guilty on account of any act or omission which did not constitute a criminal offence at the time when it was committed (nullem crimen, nulla poena sine lege praevia). In a similar vein, the penalties imposed cannot be heavier than what was applicable when the offence was committed, or collective. Finally, everyone convicted 
of a crime has the right to appeal to a higher tribunal according to law, and be compensated in certain cases of miscarriage of justice. ${ }^{36}$

Bolivia has ratified a number of human rights treaties that enshrine these standards, such as the American Convention on Human Rights and the International Covenant on Civil and Political Rights. In this context, a first question is whether indigenous disputing institutions constitute 'tribunals' according to international law. A positive answer to this question has two implications. First, that they satisfy the right to access to a court, and second, that international standards of fair trial apply to them. The Human Rights Committee defines a tribunal as 'a body, regardless of its denomination, that is established by law, is independent of the executive and legislative branches of government or enjoys in specific cases judicial independence in deciding legal matters in proceedings that are judicial in nature'. The Inter-American Court endorses a functional definition of a 'tribunal' based on its capacity to make decisive rulings that affect the rights of persons. ${ }^{37}$ The indigenous disputing forums operating in Bolivia seem to meet these requirements, although the principle of separation of powers can be said to have an external and an internal dimension. The external dimension refers to whether these institutions are independent vis-à-vis the national executive and legislative branches of government, whereas the internal dimension relates to the separation of powers within indigenous structures of governance. In the case studied here, the jurisdictional functions of indigenous authorities are separated from state branches of government, but they are part of an overarching mandate to look after the collective wellbeing of the community, including the daily management of communal affairs. This comes down to no separation from (internal) executive powers. However, this does not entail a violation of the principle of independency per se. According to the Human Rights Committee, a tribunal should be independent of the executive and legislative powers, 'or enjoy in specific cases judicial independence in deciding legal matters in proceedings that are judicial in nature'. ${ }^{38}$ In Curahuara de Carangas, indigenous norms allow the same person to embody executive and judicial tasks. It is questionable whether this constitutes an impediment to the exercise of judicial functions in a manner that is free from external pressure and conflicts of interest. As a result, some may contest whether these institutions satisfy the right to access a court according to international law. ${ }^{39}$

36 UN Human Rights Committee, General Comment 32 on the Right to Equality before the Courts and Tribunals and to a Fair Trial, UN Doc CCPR/C/GC/32 (2007). See also BurgorgueLarsen et al (2011: 659), Medina (2014), Shah (2010) and Tapia Pinto (2008).

37 See Medina (2014: 191).

38 ibid.

39 During the fieldwork, no complaints were registered about this feature of indigenous justice institutions. 
As regards the applicability of fair-trial standards to these institutions a positive answer is in order. Although the indigenous disputing forums discussed here do not always determine the outcome of a case, they have the capacity to make decisive rulings affecting the rights of persons. As explained before, indigenous authorities are in the first place tasked with facilitating an outcome that is agreed upon by the litigants. It is when no consensus is reached and/or when there is a significant communal stake that a 'ruling' is imposed by indigenous authorities or the assembly. In any case, insofar as indigenous disputing institutions make or uphold enforceable decisions about entitlements, duties and sanctions, it is pertinent to ensure that the processes in which these decisions are made are not arbitrary or allow for abuses of power. Moreover, the Human Rights Committee, in its General Comment 32, holds that Article 14 of the ICCPR (on the right to a fair trial) applies where a state recognises courts based on customary law, which are expected to meet 'basic requirements of fair trial'. ${ }^{40}$ Finally, the right to a fair trial is guaranteed by several articles of Bolivia's Political Constitution, which are applicable to indigenous justice. ${ }^{41}$ That said, it is necessary to consider how the context and logic in which these disputing institutions are embedded affect the interpretation of the different elements of this right.

Fair-trial standards are crafted upon an adjudicative model of justice, in which a third party determines someone's guilt and punishment, or balances the rights and obligations of two parties in a dyadic relationship. This entails similarities, but also differences, as compared to the disputing institutions discussed here. In particular, differences in the aim of the disputing process and the role of third parties therein seem to have implications in terms of the interpretation of certain elements of this right. In Curahuara de Carangas, the aim of indigenous dispute processes is to ensure the reproduction of communal life by restoring broken relationships, which entails addressing the root causes of the conflict and correcting deviant behaviour. In certain cases, this is impossible, which results in decisions to remove the (f)actor(s) that are perceived to disrupt a certain communal order. In other words, the outcome of these processes is considered to affect not only the litigants but, explicitly or implicitly, also corporate interests. Therefore, within their jurisdictional functions, indigenous authorities are expected to protect the collective wellbeing. This is also the aim of decisions made within general assemblies.

Against this backdrop, a first aspect of the right to a fair trial that needs to be reconsidered is the requirement of impartiality of the judge. In contexts of close community ties, it seems probable that third parties intervening in

40 However, the Committee does not specify what these 'basic' requirements are. General Comment on the Right to Equality before the Courts and Tribunals and to a Fair Trial, UN Doc CCPR/C/GC/32 (2007).

41 Arts 115, 116, 117, 119, 120 and 121 Political Constitution of 2009. 


\section{Giselle Corradi}

a case (either the indigenous authorities or the communal assembly) have prior knowledge of the litigants and the conflict. In those cases in which the role of these actors is to mediate a solution amongst the litigants, prior knowledge may facilitate this and may not necessarily mean a breach of this standard. That said, the requirement of subjective and objective impartiality seems to be part of indigenous procedural norms in the sense that indigenous authorities are expected not to let private personal stakes or opinions favour one party over the other. As a matter of fact, when an indigenous authority is too close to either party, he is not considered the right person to handle a case, which may determine whether the sullka or the awatiri should do so. However, this aspect of the right to a fair trial is not endorsed when it is the communal assembly that decides a case. Disconformities with the performance of indigenous authorities may be the subject of discussion at communal assemblies. Therefore, even if not all disputes are (made) public, the possibility of public scrutiny is a relevant means of accountability within indigenous normativity.

Regarding the competence of the judge, the requirements that the capacity of the decision-maker to hear a case is established in advance by law, and that there are clear procedures and criteria for his appointment and removal, are also part of indigenous law. This is reflected by the existence of rules stipulating the role of different layers of indigenous authority and the communal assembly. However, it is necessary to question which law is given precedence in establishing who is a competent judge in Bolivia. State and indigenous legal orders are often at odds regarding what falls within the jurisdiction of indigenous justice. Since both legal orders may be mobilised by indigenous and non-indigenous litigants as well as indigenous and state justice providers to legitimate or undermine claims to authority, this aspect of the right to a fair trial may be quite instrumental in the contestation of power relationships between dominant and subaltern groups, but also within indigenous communities. As a result, it may be problematic to take either legal order as the point of departure for assessing compliance with this standard without understanding the interests and power dynamics at play in each particular case.

Regarding standards of equality between the disputing parties, factors such as the social capital of a litigant and gender ideologies influence to a large extent whether endorsing a certain decision is perceived to serve the collective wellbeing or not. Even if all community members are entitled to resort to an indigenous authority when they have a grievance, and have the same opportunities to present arguments and challenge those of the counterparty in a hearing, equal treatment 'in court' is influenced by the position of the litigants within a web of relationships, connected to individual and collective interests. This may result in different forms of procedural discrimination. For example, cases that are similar in substance may be appraised differently, or enjoy different levels of community support for 
enforcement purposes. As demonstrated by anthropological research on disputing processes, mediation and negotiation require conditions of relatively equal power between the disputing parties (Nader and Todd 1978). This is not necessarily so in all cases handled by indigenous justice, which may lead to differential treatment due to power asymmetries amongst community members. Yet considering the origins of such unequal treatment, it seems unlikely that procedural standards alone constitute an efficient remedy to counter these forms of discrimination.

With regard to guarantees of due process, several standards set by international law seem to be part of the indigenous normativity examined here. For example, the accused is informed of the charge and has the opportunity to defend himself, present witnesses and evidence. He is tried in person, without undue delay and in a language that he understands. He cannot be charged twice for the same offence, or held guilty for an act or omission which was not considered an offence when it was committed. Regarding the principle nullum poena sine lege, the disputing institutions discussed here endorse sanctions and forms of compensation on the basis of what is negotiated as a 'solution' in each case. Although the exact scope and form of sanction or compensation may fluctuate from case to case, these institutions seem to endorse this requirement as they resort to a range of (mostly orally defined) possible measures to deal with a certain offence. In addition, these institutions seem to be concerned with the proportionality between the severity of a sanction and a certain misconduct. ${ }^{42}$ Finally, the accused also has the possibility to appeal, which can be done by resorting to another level of indigenous authority or to state justice. Other standards of due process seem less adapted to this context. A case in point is the right to communicate with legal counsel. Since the disputing process does not involve specialised knowledge, litigants normally have the skills to defend themselves.

Furthermore, certain guarantees of due process are endorsed by indigenous law in some cases, but not always-for instance, whether an accused should be afforded time and means to prepare his defence, or be presumed innocent. This is the case when there are mutual accusations between community members, leading to an investigation about the responsibility of each party by indigenous authorities. However, in cases in which most community members are convinced of someone's misbehaviour, these guarantees do not exist. In such cases, it is considered that giving the accused time or means to prepare his defence may be counterproductive. First, since it is deemed of utmost importance to treat such cases in an assembly as soon as possible. And second, because this would allow the defendant to think of

42 Admittedly, disagreements may arise as to what is proportional since the same conduct may be valued differently throughout time. Disagreements about proportionality may also exist within and across different segments of society. The reflections presented in the conclusion would apply to such situations. 


\section{Giselle Corradi}

excuses, which could lead to impunity. Despite these rationales, it remains a moot point whether disregard for these guarantees opens the door for arbitrary decisions. In addition, in such cases, coercive means may be justified in order to extract a confession, and it may be considered legitimate that the sanctions imposed also affect the family of the accused, particularly in cases that are sanctioned by banishment from the community. Finally, some of the decisions made by indigenous disputing forums are based on evidence that requires bridging different ontological and epistemological frameworksfor instance, the use of juramentos or the imposition of sanctions related to the crimes committed by kharisiris. From a 'Western' perspective, reliance on these forms of proof may be considered inconclusive, leading to breaches of fair trial guarantees such as in dubio pro reo. These may be seen as the main areas of tension between indigenous procedural norms and fair-trial standards.

On the whole, the relationship between the normative bodies examined here is multifaceted. On the one hand, certain elements of this right seem to require a flexible interpretation. On the other hand, there are areas of overlap and of tension. So how should these gaps between indigenous law and human rights be addressed? This chapter rests on the premise that such endeavours require attention to the history of oppression of indigenous peoples. This history makes it problematic to assume that these gaps can be simply declared a violation of human rights from a Western locus of enunciation. This would amount to reproducing the power asymmetries that have characterised the relationship between dominant and subaltern forms of knowledge since the colonial encounter. Therefore, in contexts of official legal pluralism, state policies, legislation and case law need to facilitate the emergence of spaces in which various normative and epistemological frameworks can be combined to inform dialogues around these issues, leading to the interpretation and protection of human rights in an inter-legal and crosscultural manner. It is to this point that the conclusion turns.

\section{CONCLUSION}

This chapter started from the concern that in contexts of official legal pluralism, such as Bolivia, human rights law imposes a duty on the state to ensure that indigenous legal orders meet international standards. This entails the delicate tasks of evaluating compliance and protecting human rights in a cross-cultural manner, while taking measures for the fulfilment of human rights by different legal orders. The material presented here illustrates the complexities involved with regard to the right to a fair trial. The analysis demonstrates that different forms of social organisation and modes of dispute-processing influence how arbitrariness and abuses of power may manifest at the procedural level, and hence, which standards may be applicable 
to prevent this. The case study on indigenous disputing institutions in Curahuara de Carangas shows that factors such as the aim of the disputing process and the role of third parties therein interplay with the relevance and appropriate interpretation of certain elements of this right in different disputing contexts. At the same time, the chapter identified a few areas of overlap and of tension between indigenous and human rights law. This raised the question as to how these gaps may be addressed.

Although answering this question deserves more than the few lines available for a concluding section, two issues are key. First, the actors and registers of law that are involved, and second, the power relations in which such processes are embedded. In contexts of official legal pluralism, it seems fair to expect that states take measures to enable these areas of tension to be dealt with by means of inter-legal and cross-cultural dialogues (Inksater 2010). ${ }^{43}$ As explained in the introduction of this edited collection, legal pluralism is conducive to 'inter-legality' (Santos 1987). Exposure to various normative repertoires, disputing institutions, authority regimes and societal models in general, contributes to the mixture and interpenetration of elements from different legal orders in people's minds and actions. This precludes an essentialist understanding of the relationship between 'a legal order' and 'a people', while it directs our attention to the processes in which contact with various normative models interplays with the development of inter-legal legal subjectivities. The spaces in which these mixed subjectivities take shape may constitute privileged sites for dialogues on human rights.

However, which measures may facilitate this? Which actors should participate and in which spaces can such dialogues take place? Although not exclusively, disputing processes open considerable opportunities for this since a multiplicity of actors may contribute by bringing up different understandings of the relationship between indigenous norms and practices and human rights in concrete situations. In such cases, areas of tension between indigenous legal orders and human rights could be addressed by 'mixed tribunals' in which authorities representing different legal orders handle cases together (Yrigoyen 1999). On the one hand, this could prevent human rights being understood according to a dominant perspective, and on the other, it could facilitate dissident voices to question indigenous norms and practices in a way that neither alienates critiques from an indigenous space, nor allows for communal silencing.

In Bolivia, the 'Plurinational Constitutional Tribunal' is supposed to represent a mixed tribunal, as it is composed by seven judges of which at least two are of indigenous origin. However, constitutional judges need to have a law degree and at least eight years of specialisation in the field of constitutional law, administrative law or human rights, while having exercised the

43 Inksater (2010) uses the concept 'transformative juri-cultural pluralism' to group the dimensions 'inter-legal' and 'cross-cultural' in human rights dialogue. 


\section{Giselle Corradi}

function of indigenous authority is only considered as an asset (Law on the Plurinational Constitutional Tribunal, Article 17). As a result, it is debatable whether this tribunal can be seen as truly inter-legal and cross-cultural. Moreover, only a few disputes may find their way up to this level. Therefore, this chapter argues that mixed disputing forums should also be foreseen at lower jurisdictional levels, and in particular at the grass roots, where more communal involvement is possible. Such collaborative spaces of joint action need not be permanent, but could be activated when there is a need for it-for example, whenever a litigant claims that indigenous justice does not respect his or her human rights, or when there is a claim that state justice is not responsive to the understanding that an indigenous community has of a certain case in which human rights are at stake. At present, Law 073 on Jurisdictional Delimitation only establishes that state and indigenous justice will coordinate and cooperate with each other, and lists a series of broadly defined mechanisms to this end, such as exchanging information and creating spaces for dialogue (Articles 13, 14, 15 and 16). Although this law does not prohibit spontaneous forms of collaboration between state and indigenous justice providers, its rhetoric seems to assume two separate spheres of dispute-processing, and it certainly does not require joint decision-making.

The proposal advanced here requires egalitarian relationships of trust between state and indigenous authorities. This is certainly a challenge that goes hand in hand with undoing histories of domination. While in some cases, these horizontal relationships have emerged spontaneously, due to daily contact, mutual knowledge and/or the perception that it is in the interest of both parties to collaborate, certain structural factors may undermine them. For example, legislation and case law that limit the jurisdiction of indigenous justice unilaterally and against the practices of indigenous communities, while rendering them vulnerable to criminalisation, are likely to form a significant constraint. It is undeniable that constitutional provisions that recognise state and indigenous law on equal footing represent powerful tools to challenge such persistent asymmetries. At the same time, they open windows of opportunity for the materialisation of intra-community and cross-cultural dialogues on human rights, both in disputing and in nondisputing situations. But despite these advances, more sustained institutional and personal efforts will be necessary in order to alter deeply rooted patterns of sub-alternisation. 